\title{
THE “COMMERCIAL" ASPECT OF THE CONGO QUESTION
}

\footnotetext{
"It appears to me that the facts which I have stated above afford amply sufficient evidence of the spirit which animates the Belgian Administration, if, indeed, Administration it can be called. The Government, so far as I could judge, is conducted almost exclusively on commercial principles, ${ }^{1}$ and, even judged by that standard, it would appear that those principles are somewhat short-sighted."-Lord Cromer, Whits Book, Africa, Na. I, 1904, P 2.

"ThE Government, so far as I could judge, is conducted almost exclusively on commercial principles. ..." The sentence illustrates an aspect of the Congo question I make bold to say, very little understood, but without understanding which the Congo question is itself incapable of being thoroughly understood. It raises issues, moreover, of immeasurably wider import than the methods of Congo Government rule per se. The words " commercial principles," while strictly accurate in the connection in which they are applied, are, nevertheless, open to misconstruction when viewed from the general standpoint of what constitutes commerce in tropical Africa. The meaning which Lord Cromer attaches to the expression he uses is not, I venture to assume, open to doubt. He intends to convey that the policy, or shall we say the ideals, of those whom Europe set over the natives of the Congo, are not such as usually characterise the motives of the European rulers of African races. In other words, that "administration" as the term is universally understood, is subordinated to purposes of gain, or-since a Government and not a trading company is concerned-to purposes of acquiring revenue. We need not, valuable as Lord Cromer's judgment must be in the eyes of all Englishmen acquainted
}

\footnotetext{
1 Italics are mine-Author.
} 
THE " COMMERCLAL" ASPECT OF THE CONGO QUESTION 43I

even superficially with his great career, corroborated as that judgment is by Consul Casement's report, and by the unpublished (but epitomised) reports of British officials in territory adjacent to that of the State, to say nothing of a mass of unofficial testimony, of which the greater portion is above suspicion, go beyond the declarations of Congo Government officials themselves, to appreciate the significance attaching to his lordship's description. The following examples will suffice :-

I.

M. Felix Fuchs, Governor ad-interim of the Congo State to Commandant Verstraeten, in charge of the Rubi-Welle zone.

"Je terminerai en vous disant que le Gouvernement a le ferme espoir que, vous inspirant des considérations expostes en tête de la presente, vous fournirea une nouvelle preuve d'activité et de dérouement, en faisant produire à la zone que vous commandez le maximum de ressources qu'on en peut tirer. 1

II.

Commandant Verstraeten to the Chefs de posts of the Rubi-Welle zone.

" J'ai Phonneur de porter à votre connaissance qu'à partir du Ier Janvier, 1899 , il faut arriver a fournir mensuellement 4,000 kilogrammes de caoutchouc." 2

III.

Governor General Wahis to Commissioners of districts and Chiefs of 20nes.

"A cette cause de la diminution de la valeur du caoutchouc, il faut ajouter celle parvenant de Pemballage defectueux du produit qui par suite voyage souvent pendant plusieurs mois dans les plus mauvaises conditions. L'on peut dire qu'à cause de cette négligence une notable partie des efforts qui ont éte faits pour obtenir une production en rapport avec la richesse du pays doivent être considérts comme perdus, puisque la valeur du caoutchouc peut diminuer de moitie par suite de ce manque de soin. J'ajouterai que la valeur du caoutchouc, même pur de tout mélange, a diminué depuis quelque temps sur tous les marches; il faut donc que les Chefs Territoriaux fassent non seulement disparaitre les deux causes de pertes qu'ils peuvent eliminer, mais encore quilis compensent la troisieme en faisant des efforts continus pour augmenter la production dans la mesure prescrite par les instructions. Mon attention sera d'une façon constante, fixte sur les prescriptions que je donne ici."

1 Ameales Partiamentaines (Congo debates: Belginn House, Jaly, t903).

8 Ibid.

White Book, op. cit. 
It may be surmised that the anxiety thus indicated by those in supreme and high authority on the Congo, to increase above all things the rubber output of the country, cannot fail to be reflected in the successive scales of hierarchical appointment down to the most humble Government employé. The expression " commercial principles," used by Lord Cromer, so far as it applies to the ideals presiding over Congo Government rule is, therefore, easy of comprehension. It is when we ask ourselves, or are asked the question, "What are we, in point of actual fact, to understand by the word 'commercial ' in its relation to transactions between the European and the African in tropical Africa?" that the confusion in men's thoughts, apparent in so many epistolary and oral communications devoted to the Congo question, arises.

Nothing, I submit, can be clearer than that although the policy of the Congo Government, as Lord Cromer says, is " commercial" in conception, it is not "commercial" in practice. If we pass from the sentiment-the nature of which is established - to the performance-the nature of which remains to be examined-the word "commercial " applied to the latter will be seen to be an entire misnomer. And it is precisely at this point that we find ourselves face to face with a bewildering maze of contradictory assertions, a thicket of doubts close set with thorns, through which we must push our way, for in the midst, concealed by many a layer of tangled undergrowth, not altogether the product of natural selection, is to be found the key which unlocks the problemas some still think it to be-of the Congo.

Let us then, answering the question put down above, begin at the beginning of things, dealing broadly and in limited space with the subject. On the one hand, Europe : Europe inhabited by races, ceaselessly increasing, seeking new outlets for their manufactures and industries, where the struggle for existence is keen, and often bitter. On the other, Tropical Africa: Tropical Africa inhabited by races of relative low development, imbued naturally with a pronounced aptitude for bargaining, good traders; living in a land endowed with vegetable riches required by European industrialism, riches which the native alone can gather. At a given moment con- 
THE " COMMERCLAL" ASPECT OF THE CONGO QUESTION 433

tact is established. What is the basis of the relationship thus spontaneously created? The basis is a "commercial" one. The European merchant seeks to light in the breast of the primitive African a desire for European merchandise, and to obtain from the African in exchange raw produce which can be sold in Europe at a profit. Behind the European merchant, who is the middleman pioneer, stands the European manufacturer searching a wider field where his products may be marketed with advantage; behind the European manufacturer stand all the elements which constitute the driving force of racial and industrial expansion. The African is attracted by the wish to become possessed by purchase of articles, many previously unknown to him ; others of which he at once grasps the utility, being perfected examples of what he himself has rudely fashioned for his own purposes. Behind the African is the propelling strength of instinct ; the instinct of primitive man, to increase his comfort, his well-being, his knowledge and his power. And so, by degrees, the African grafts voluntarily upon the labour necessitated for his own sustenance in food stuffs, and the up-keep of his own rudimentary industries, the labour, often extremely arduous, demanded for the collection and cultivation of articles produced by his forests and his plains, with which he can alone obtain the European goods he desires. And so, too, by degrees, a fair basis of sale and purchase is established, as between the European who supplies the wants of the African, growing as contact is prolonged and extended, and the African who alone is able to collect the produce with which to supply the wants of the European. The European merchant has found another sphere for his activity and enterprise, the European manufacturer another market for the products of his looms and workshops; the African has found an unexpected market for the products gathered by his labour.

That, in brief, is the history of European "commercial" relationship with tropical Africa; and the voluntarily assumed labour of the African for the acquirement of European merchandise in the British, French, and German West African possessions has led in the last five years to a production, in 
Africa, by the African, valued at $£ 24,000,000$ sterling. That, in brief, has been, notably, the history of the Congo prior to 1892. The pronounced commercial instinct of the native of the Upper Congo, whence the bulk of produce shipped from the lower river originated, is attested by many authorities, Stanley amongst them.

Thus the word " commercial," applied to transactions between the European and the African in tropical Africa, is found to necessitate entities, to involve two conditions. A seller, a purchaser : the possession by the seller of articles to sell : the possession by the purchaser of articles wherewith to purchase. If we eliminate one or other, or both those entities : one or other, or both those conditions, it must be obvious to the meanest understanding that "commercial" relationship is itself eliminated. If, notwithstanding the elimination of this commercial relationship, the African continues to produce in large quantities those articles which are required by European industrialism, and which, let it be repeated, he alone can gather, then, again, must it be obvious to the meanest understanding that the relationship between the European and the African in tropical Africa has altered, and that whatever it may be it is not and cannot by any possibility be "commercial."

I have stated deliberately that the political conception of the Congo Govern.nent is not "commercial" in practice, although it is so in principle. An examination of the export statistics of the Congo State shows us that the total export of produce in the four years, $1899-1902$, amounted in value to the very large figure of $£ 7,360,130$, indiarubber being represented by $£ 6,146,974$.

Let us consider then what the relationship may be which has resulted in this vast expenditure of native labour on noncommercial lines. It has been asserted, and the assertion has been denied, or more correctly, evaded, that the basis upon which reposes the political conception of the rulers of the Congo is that of State or State-delegated appropriation of the soil, and the products of economic value growing thereon. We read, for example, in the English translated edition of the 
THE " COMMERCIAL" ASPECT OF THE CONGO QUESTION 435

Bulletin Officiel, for June, 1903, the following remarkable statement :-

"Liberty of commerce is complete in the Congo and is not restricted by any monopoly or privilege. Everyone is free to sell or to buy all prodace in which the traffic is legitimate"

It will be noticed that the second sentence is susceptible, under given circumstances, of cancelling the first. The first tells us that liberty of commerce is complete; the opening of the second one informs us that every one is free to sell or to buy all produce. (The exports from the Upper Congo consist of three articles, indiarubber, ivory, and gum-copal.) But the second sentence concludes with an important reservation; the produce which every one is free to sell or to buy must be produce, the sale and purchase of which is legitimate. If, therefore, it should happen that indiarubber, for example, which holds the paramount position in the exportable articles from the Upper Congo, were not considered as belonging to the category of produce in which the sale and purchase is legitimate, we should be confronted with a reductio ad absurdum of the contention as to liberty of commerce being unrestricted. In any case we should have extreme difficulty in reconciling the assertion that "liberty of commerce" is complete with an established fact : to wit, the portioning of the vast Upper Congo into a number of territorial sections, known as the Domaine Prive, the Domaine de la Couronne, the Anversoise, A.B.I.R., Kasai, Katanga, Aruwimi, Trusts, Erc., where the element in commercial relationship between the European and the African belonging to the latter, or, in other words, the produce of the soil has been-as we read Congo legislative enactments-either appropriated by Government, or of which Government has delegated the ownership to Corporations of whose profits it is admittedly the largest recipient, and whose organisation it effectually directs and controls. Happily for the mental equilibrium of mortals unendowed with any very pronounced subtlety of reasoning, and lacking in the higher flights of judicial casuistry, the Congo Government has now definitely disfosed of a previous ambiguity which may, not unreasonably, be said to have clung to propositions containing within them the germs of mutual destructiveness. 
Replying to that part of the British Note which affirms the right of the native to dispose freely of the produce of his soil, "so long as the produce can only be collected by the native" -that is to say, as we are concerned with tropical African conditions, so long as the world lasts-the Congo Government remarks :-

aThe note confuses the utilisation of his property by the orumer with trade. The native who collects on bekalf of the owner does not become the owner of what is so collected, and naturally cannot dispose of it to a third party. ...."

\section{And again :-}

"Though the system thus adrocated cannot be applied in the Congo State, as there ans wo longer any wmappropriated lands there. . . ."

These admissions render any further exposition superfluous. We have it now on the authority of the Congo Government itself that the ownership of the produce of the soil which, as already shown, affirmed and here repeated, is the element in the commercial relationship between the European and the African belonging to the latter, has passed away from the African, and has become vested in the Government; and that in collecting such produce the African is not, in effect, gathering what belongs to him by virtue both of ownership and labour, but is collecting what belongs to some one else. The second quotation makes it abundantly evident, moreover, that the Congo Government not only applies this principle to the territory where the produce of the soil has been appropriated by Government, but also to such portions of its demesne in which the produce of the soil has been, or may in the future be, delegated by Government to Corporations allied to it, and ostensibly founded on a "commercial " footing-" as there are no longer any unappropriated lands there. . . ." I shall have occasion in a moment to bring forward evidence proving how accurate is the above definition thus employed by the Congo Government to characterise the political conception it has evolved for the management of the territories assigned to it by civilisation, when the actual working out of that political conception in practice is studied. 
Meanwhile, let us realise our bearings from the point we have now reached in our journey through the thicket of contradiction, armed with the matchet of logic.

It has been demonstrated that the commercial relationship between the European and the African in tropical Africa necessitates two entities, and involves two conditions, viz., a seller, a purchaser; the possession by the seller of articles to sell, the possession by the purchaser of articles wherewith to purchase. It has been demonstrated that the elimination of one or other, or both these entities, one or other or both these conditions, involves the disappearance of the commercial relationship, and its substitution by something else. Finally, it has been demonstrated that in the Congo territories one of the two entities, and one of the two conditions, have been eliminated, viz., the purchaser, and the existence of articles wherewith to effect purchase. It will, moreover, not escape attention that the circumstance entails a radical change in the condition of the seller, the possession by him of articles to sell being henceforth an optional matter, since, in point of fact, the articles he requires are theoretically his without any such tedious transaction.

Now whatever other effects-we may leave them out of our calculations for the present-this elimination of the commercial relationship between the European and the inhabitant of tropical Africa may have, it must needs entail an entire revolution in the life, in the horizon of the African. He becomes de facto a tenant where he was a landlord, a servant where he was an owner, deprived at a stroke from a source of actual and potential wealth, and relegated to a position where his evolution inevitably becomes arrested with the loss of his personal liberty of action. And so far, be it noted, we are only dealing with the negative effects of the destruction of commercial relationship. Its positive effects, in the character of the new relationship substituted for the commercial relationship, its physical and moral results-this we have left entirely untouched.

And now, another question forces itself to the front, or rather two questions. "How comes it that, notwithstanding the elimination of commercial relationship between the 
European and the African in the Congo territories, the natives of those territories have collected raw produce in four years amounting in sterling to the enormous sum of $£ 7,360,130$, of which $£ 6,146,974$ is represented by indiarubber? How comes it that the Congo natives, who no longer own that produce either before or after its collection by them; in whose eyes, therefore, it can no longer be regarded as representing a purchasing capacity in European goods, the sole medium, in the absence of currency with which to acquire such goods; how comes it that the Congo natives still collect this produce, and in ever-increasing quantities?"

Does not the circumstance in very truth appear at first sight an unfathomable riddle? In solving it we shall run up against many more extraordinary and equally self-destructive propositions. If, for example, we turn to the official import and export returns of the Congo State, we are astonished to see them headed "Commerce." But we have by now travelled far enough along the road-hewed our way sufficiently through the thicket to retain the metaphor-to know that the word "commerce" must be a misnomer. The commercial relationship has gone. And so we seek, and find, a partial explanation in the revenue and expenditure returns, noting therefrom that a considerable portion of the exportswe shall presently be called upon to dissect the relative proportion between imports and exports-is composed of produce obtained by "taxation" of the natives in the Domaine Privé. And, as we were made aware, from the declarations of $M$. le Baron de Favereau and of M. le Comte de Smet de Naeyer in the Belgian House last July, that the value of the produce obtained by "taxation" of natives in the Domaine de la Couronne is not accounted for publicly, but is made over to a private fund managed on behalf of the Sovereign of the Congo State by M. le Baron Raoul Snoy, M. le Baron Goffinet, and M. Droogmans ; we are driven to the conclusion that the proportion of the produce thus obtained from the Congo natives to the total produce exported is much more

1 Arrales Parlianentairs.

2M. Droogmens is the Finnace Minister of the Congo State: Baron Snoy and Baron Goffinet are attached to the Court. 
THE " COMMERCIAL" ASPECT OF THE CONGO QUESTION 439

extensive than the official returns disclose. One cannot help remarking, in passing, upon the singular inconsistency which (I.) admits the elimination of commercial relationship; (II.) heads the import and export statistics by the word "Commerce"; (III.) incorporates in those export statistics the produce obtained from taxation."

A large portion, a far larger portion than is inscribed in any public document, of the $£ 7,360$, I 30 of produce collected by the Congo natives in four years, has thus been obtained not as the outcome of a "commercial" transaction, but in order to provide revenue for the Government (so far as the Domaine Privé is affected), and for the Sovereign-King (so far as the Domaine de la Couronne is affected), in the form of " taxes." So much is manifest.

The inherent right of a Government to tax its subjects will not be queried-apart from difference of opinion as to the form which such taxation may wisely or unwisely take-so long as the amount imposed bears some relation to the wageearning and general capacity of the tax-payer. It may be observed in this connection, that whereas the British, French, and German Governments are content to tax their African subjects once or at most twice a year, the Congo Government, as is apparent from the White Book and from numerous private reports unassailable in character, prefers to tax its subjects once a fortnight, or once a week, which, for revenue purposes, is no doubt an excellent thing for a Government whose principles, as Lord Cromer says, are " commercial," and which explains in great measure the solicitude displayed by the supreme authorities on the Congo on this subject, a solicitude of which some indications were given in the opening pages of this article. The inherent right of a Sovereign absolute, residing in Europe, to tax his African subjects for purposes, and to an extent unexplained and unaccounted for, over and above, outside and apart taxes applied by Government for revenue requirements, is not, perhaps, so clear.

With regard to taxation imposed for Government needs, the Congo Government and its supporters have sometimes urged that, in order to alleviate somewhat a possible but by no means officially recognised burden upon the native tax-payer, 
the said tax-payer is paid something in return for his trouble in collecting rubber, ivory, or gum-copal, as the case may be. Some estimate may be formed of the nature and extent of this return by the extract from the White Book given in the footnote. ${ }^{1}$ But M. le Comte de Smet de Naeyer, defending the Congo Government's methods-from which, good or ill, it will be remembered that the Belgian Government has on two occiasions ${ }^{2}$ disclaimed all responsibility, together with any especial locus standi justifying an inquiry on the part of Belgium-has declared categorically that such return payment is purely optional, and must be regarded as evidence of the generous instincts of the rulers of the Congo State towards the natives :-

"Ils g'ont droit a rien, ce qưon leur donne est une véritable gratuite." "

Nothing could be more specific.

The facts given above are merely confirmatory of our demonstration as to the disappearance of the commercial relationship between the European and the African in the greater part of the Congo territories-the part, that is, where the Government has constituted itself owner of the produce of the soil - and confirmatory of the definition of tenure as between

\footnotetext{
1 The value of the annual payment in gum-copal made by cach town woold seem to be about $£ 360$, while at an average of 7 fr. as the remuneration each receives fortnightly, they wonld appear to receive some $6_{1} 10$ in annal return. In the village of Montake, at the south end of the lake, where I spent two degs, the people seemed, during my stay, to be chieffy engrossed in the tusk of chipping and preparing the gum-copal for shipment to Bikoro. . . I I saw the filling with gam of the ten basket-sacks taking place under the eyes of the Chief-who himself contribated-and a State sentry who was posted there. Each houschold in the town was represented at this final task, and every adult bouseholder of Montaka shared in the general contribation. Assuming the popalation of Montake et from 600 to 800 -and it carnot now be more, although a town of 4000 souls ten years ago-fully 150 householders are thus directly affected by the collection and delivery, each fortnight, of this "imp6t en nature, ${ }^{n}$ and are affected for the great majority of the days throughout the year. Since for the 61 tons of gum-copel which the 150 bonseholders of Montake contribute ennually, they are geen to receive not more then a total payment of $\delta$ IO in the year -vir fortnightly payments of on an average $9 \mathrm{fr}$. 50 , igiving $247 \mathrm{fr}$. annually-it follows that the remuneration each adult householder of Montaka receives for his entire year's work, is the one hundred and fiftieth part of that total-or just is. 4d. This is just the value of en adult fowl in Montake."

Anerales Parliamentaines, 1900 and 1903. Speeches, notably, of M. le Comte de Smet de Necyer.

Annales Parliamentaires, 1903.
} 
THE " COMMERCIAL" ASPECT OF THE CONGO QUESTION 441

the European and African, given by the Congo Government itself in its reply to the British Note.

The point has already been noted that the definition referred to covered not only the area reserved to Government and to the Sovereign but the ENTIRE area, inclusive, therefore, of the many tens of thousands of square miles where ownership of the produce of the soil has been delegated to Corporations connected with Government, although ostensibly run on "commercial" lines. On that score the definition is, to my mind, perfectly clear. We are all, however, subject to error. The writer is not at the inquiry stage, but has long passed the conviction stage in regard to the Congo question. He may, therefore, be prejudiced or incapable of approaching the subject impartially; he may read into that definition something which is not there. And at first, it would almost seem as though some foundation existed for the charge. Thus of the Trusts or Corporations alluded to, that operating in the Mongala is called the "Société Anversoise du Commerce au Congo." Surely the commercial relationship must at least have been retained in the Mongala region? The "A.B.I.R.'s" 1 objects are "Faire dans les limites les plus étendues toutes opérations commerciales...." The "Kasai's" objects are described in the statutes as "La récolte et le traffic des produits végétaux et de l'ivoire et de toutes opérations d'exploitation, d'exportation et d'importation commerciales. . ." And so with the others. And yet these circumstances, notwithstanding, I submit that "commercial " relationship between the European and the African on the territories allotted to the Anversoise, the A.B.I.R., the Kasai, the Katanga, \&c., that the terms "commerce," or "commercial" embodied either in the statutes or in the titles of these Corporations, that these expressions are complete misnomers; and that the status of the natives living within the regions thus allotted is identical with the status of the natives inhabiting the regions where the produce of the soil is either appropriated by Government (Domaine Prive), or by the Sovereign-King (Domaine de la Couronne), where the collec-

1 Billows Conpolais. Alfred Postine.

- Mourvont Gtographique, January 5, 1902 
tion of such produce by the inhabitants takes the form of "taxation" levied fortnightly or weekly by authority.

To go through the records of every Corporation in order to show that the system prevailing is identical in each would be tedious, if not to the writer at least to the reader. We will content ourselves, therefore, with the Anversoise and the A.B.I.R., the two Trusts whose reputedly "commercial" operations, being conducted as they are within relatively easy distances of the main highway of civilisation in that far-distant country, the Congo River itself, have lent themselves more easily to study and appreciation. So far as the Anversoise is concerned, its whole hideous and, indeed, appalling history, chronicled not in anonymous newspaper paragraphs, but in the law-courts of the Lower Congo, provides proof sufficient to convince the most sceptical of mortals that the relationship between the agents of the Corporation (in which the Government is the largest shareholder, receiving in addition a substantial royalty on all produce exported), and the native is not, at any rate, "commercial" in nature. The latest official document available from this part of the Congo-the verdict of the Boma Appeal Court of I $^{\text {th }}$ March, 1904, in the case of the men Caudron and Silvanus Jones ${ }^{1}$-is, however, sufficiently specific to absolve us from pushing our inquiry to any greater lengths. It transpired in the course of that trial that in April, 1901, the Governor-General of the Congo State authorised by a letter, which was incorporated in the dossier, the "Société Anversoise du commerce au Congo," to " exact rubber as a tax from the people," decreeing in the event of non-compliance the "bodily detention of the defaulters." This letter was quoted by counsel for the defence as a justification for the act of his client (one of the counts of the indictment against Caudron) in detaining twenty natives in prison for that offence. The President of the Appeal Court, while declaring that the said letter could not be held to have the force of law, as no law to that effect was, at the time the letter was written, on the Statute-book, and refusing on those grounds to allow the validity of the plea of justification-the Governor-

1 Wast African Mail, Congo Supplement, May (Official orgen of the Congo Reform Associntion). 
General, who, by the findings of the Appeal Court, stands convicted of having authorised an act which was illegal has not, it would seem, yet been impeached-nevertheless went on to admit that a "similar law" had become operative since. The agents of the Anversoise are, therefore, now entitled by law to exact indiarubber from the natives as a "tax," and consequently the relationship between the European and the African in a region where a Corporation, whose title includes the word "commercial," operates, is precisely the same as that which pertains in the Domaine Prive and the Domaine de la Couronne, into the former of which, it appears, the Mongalla region is to be shortly re-incorporated. Obviously, the relationship is not "commercial."

In respect to the $A . B . I . R$. territory, I do not think I can do better than quote the testimony of H.B.M. Consul in the Congo, from the White Book.

"The explanation offered me of the state of things was that, as the 'impositions' laid apon the natives were regulated by law, and were calculated on the scale of public labour the Government had a right to require of the people, the collection of these 'impositions' had to be strictly enforced. When I pointed out that the profit of this s) stem was not reaped by the Government, but by a commercial Company, and figured in the public returns of that Company's affairs, as well as in the official Government statistics, as the outcome of the commercial dealings with the natives, I was informed that the 'impositions' were in reality trade, 'for as you observe, we pay the natives for the prodace they bring in.' 'But,' I observed, 'you told me just now that these products did not belong to the natives, but to you, the Concessionnaire, who owned the soil ; bow then, do you buy from them what is already yours?' 'We do not buy the indiarubber. What we pay to the native is a remuneration for his labour in collecting our produce on our land, and bringing it to us.' Since it was thus to the labour of the natives alone that the profits of the Company were attributed, I inquired whether he was not protected by contract with his employer; but I was here referred back to the statement that the native performed these services as a public duty required of him by his Government. He was not a contracted labourer at all, but a free man, dwelling in his own home, and was simply acquitting himself of an 'imposition' laid upon him by the Government, 'of which we are but the collectors by right of our Concession.' 'Your Concession, then, implies' I said, 'that you have been conceded not only a certain area of land, but also the people dwelling on that land ?' This, however, was not accepted either, and 1 was assured that the people were absolutely free, and owed no service to any one but to the Government of the country. But there was no explanation offered to 
me that was not at once contradicted by the next. One said it was 2 tax, an obligatory burden laid upon the people, such as all Goveraments have the undoubted right of imposing ; but this failed to explain how, if a tax, it came to be collected by the agents of a trading firm, and figured as the outcome of their trade dealings with the people, still less, if it were a tax, it could be justly imposed every week or fortnight in the year, instead of once or at most twice a year. Another asserted that it was clearly legitimate commerce with the natives, because they were well paid and very happy. He could not then explain the presence of so many armed men in their midst, or the reason for tying up men, women and children, and of maintaining in each trading establishment a local prison, termed 'maison des otages' wherein recalcitrant native traders endured long periods of confinement. A third admitted that there was no law on the Congo Statute Book constituting his trading establishment a Government taxing station, and that since the product of his dealings with the natives figured in his Company's balance sheets as trade and paid duty to the Government on export, and a dividend to the shareholders, and as he himself drew a commission of a per cent. on his turnover, it must be trade ; but this exponent conld not explain how, if these operations were purely commercial, they rested on a privilege denied to others, for since, as he asserted, the products of his district could neither be worked nor bought by anyone but himself, it was clear they were not merchandise, which, to be merchandise, must be marketable. The summing ap of the situation by most of those with whom I sought to discuss it was that, in fact, it was forced labour conceived in the true interest of the native, who, if not controlled in this way, would spend his days in idleness, unprofitable to himself and the general community. The collection of the products of the soil by the more benevolent methods adopted by the Trading Companies was, in any case, preferable to those the Congo Government would itself employ to compel obedience to this law, and therefore if I saw women and children seized as hostages and kept in detention until rubber or other things were brought in, it was better that this should be done by the cap-gun of the 'forest-guard' than by the Albini armed soldiers of the Government who, if once impelled into a district, would overturn the entire country side. No more satisfactory explanation than this outline was anywhere offered me of what I saw in the A.B.I.R. and Lulanga districts. It is true alternatives of excuse with differing interpretations of what I saw were offered me in several quarters, but these were so obviously untrue that they could not be admitted as having any renl relation to the things which came before me"

The relationship between the European Agents of the A.B.I.R. (of which the Congo Government is the largest shareholder), and the natives inhabiting the area of that concession, is clearly not " commercial " in nature.

As regards the Lulanga territory, assigned to a lesser Corporation, known as the La Lulanga Company, briefly touched un in the above extract, it is only necessary to remark, in order 
THE " COMMERCIAL" ASPECT OF THE CONGO QUESTION 445

that the relationship in which the natives of this territory are placed towards the European may be understood, that the doctument purporting to be a reply to the British White Book contains the somewhat disingenuous admission that the natives "lied " to the British Consul (in the case of the little mutilated boy Epondo), "in the hope that his intervention would absolve them from the obligation de l'impst."

Is any further evidence needed to confirm the accuracy of the interpretation-the only possible interpretation, indeedgiven in this article to the published definition of the Congo Government, concerning the relationship between the European and the African throughout the entire area of the Congo territories? Has it not been made absolutely clear that that relationship is not "commercial," and, therefore, whatever it may be, is neither normal nor natural?

And yet, a solid incontestable fact stares us in the face : a fact which, under the circumstances, can only be described as remarkable. In four years the natives of the Congo have collected produce valued at $£ 7,360,130$ on the European market, of which $£ 6,146,974$ is represented by indiarubber. But I am not sure that the fact is more remarkable than are the entire official statistics relating to what is entitledwrongly, as we have proved-the "commerce" of the Congo State; that is to say the returns both of imports and exports in those four years. The white population of the Congo State is 2,400 ; there is a regular native army of 19,000 men; there is an irregular native army estimated by H.B.M. Consul in the Congo at 10,000, in my humble opinion underestimated; there are two railways built, and one in course of construction; there is a large river flotilla; there are telegraph and telephone lines; there are an enormous number of Government military, and other stations, and stations belonging to the Trusts. There are several other things which it is unnecessary to emphasise. Now a careful comparative calculation will show that a British, French, or German tropical African possession, enjoying similar advantages, would import in four years for purposes directly and indirectly connected with Government, articles of a value aggregating, at the very least, $£ 2,500,000$; while an export of produce consisting almost 
entirely of indiarubber, and amounting to $£ 7,360$, 130, would require an import in merchandise wherewith to purchase it from the producer aggregating $£ 6,500,000$; which would still leave a decent profit to the European merchant, middleman between the European manufacturer and the native producer. In round figures then, the imports of a British, French, or German tropical African possession enjoying conditions similar, in the particulars enumerated, to those prevailing in the Congo State, would amount in the period covered to $£ 9,000,000$.

But when we turn to the import statistics of the Congo State for the aforesaid four years, we find the final proof of the elimination of commercial relationship between the African and the, European throughout those vast territories in the startling circumstance that the total imports have only amounted to $\ell_{3,529,317}$, from which a careful dissection enables us to deduct articles of a minimum value of $£ 2,636,000$ that could never by any possibility have found their way into the hands of the native producer.

I had intended dealing with the positive results of the substitution of commercial relationship on the Congo by that something else, whatever it may be, whose persuasiveness and attraction to the native is so pronounced that under the regime, he has collected produce in four years of a value of $\ell_{7,360,130 .}$ On second thoughts, however, I have decided not to do so, but will content myself with a short quotation from a document of great historical importance, in which a prediction is made that, I fear, has not altogether been fulfilled; and follow it by reproducing a paragraph or two from the White Book, giving, I think, a fairly lucid explanation of the reasons for the non-fulfilment of that prediction of which the proof is forthcoming from the statistics we have passed in review.

Extract from Manifesto of the International Association (communicated by Stanley to the members of the Manchester Chamber of Commerce, at the special meeting held at the Town Hall, on October 21st, I884) :-

\footnotetext{
"The Congo regions abound in produce of various kinds now lost to the world, although industry might turn it to such marvellous account. Thanks
} 
THE " COMMERCIAL" ASPECT OF THE CONGO QUESTION 447

to trade, all this produce will enter into circulation : the counterpart of its value will return to Africa, for which it will prove a source of prosperity."

Extract from H.B.M. Consul's report. White Book, Africa No. I. 1904:-

"Payments made to the rubber bringers, depending on the quantity brought, consisted of knives, matchets, strings of beads, and sometimes a little salt. I saw many men who got a wooden handled knife of Sheffield cutlery, good and strong-others got a matchet. The largest of these knives with a 9 inch blade, and the smaller with a 5 inch, cost in Europe, I find, $2 s$. $10 d$. and $1 s$. $5 d$. per dozen respectively, less $2 \frac{1}{8}$ per cent. cash discount. The men who got the knife of the larger kind, or a matchet, had brought in, I understood, a full basket of pure rubber, which may have represented a European valuation of some $27 \mathrm{fr}$. To the original cost of one of these knives, say 2 t $d$, should be added fully 100 per cent. to cover transport charges, so that their local value would be about $6 d$. Among the natives themselves these knives pass at 25 rods ( $1.25 \mathrm{fr}$.) and 15 rods (75 centimes) each. From two of these rubber workers, I later purchased two of these knives, giving twenty-five teaspoonfuls of salt for the larger, and six teaspoonfuls with an empty bottle for the smaller. From a third member of their party, whose payment had consisted of a string of thirty-nine blue and white glass beads (locally valued at 5 rods) I bought his fortnight's salary for five teaspoonfuls of salt. This youth, indeed, confessed that his basket of rubber had not been so well filled as those of the others. I went to the homes of these men some miles away and found out their circumstances. To get the rubber they had first to go fully a two days journey from their homes, leaving their wives and being absent for from five to six days. They were seen to the forest limits under guard, and if not back by the sixth day trouble was likely to ensue. To get the rubber in the forests-which generally speaking are very swampy-involves much fatigue and often fruitless searching for a well-flowing vine. As the area of supply diminishes, moreover, the demand tor rubber constantly increases. Some little time back I learned the Bongandanga district supplied 7 tons of rubber a month, a quartity which it was hoped would shortly be increased to 10 tons. The quantity of rubber brought by the three men in question would have represented, probably for the three of them, certainly not less than $7 \mathrm{kilog}$. of pure rubber. That would be a very safe estimate, and at an average of seven fr." per kilog. they might be said to have brought in $\$ 2$ worth of rubber. In return for this labour, or imposition, they had received goods which cost certainly under Is., and whose local valuation came to 45 rods (Is. IOd.). As this process repeats itself twenty-six times a year, it will be seen that they would have yielded $£ 52$ in kind at the end of the year to the local factory, and would have received in return some 245. Or 255. worth of goods, which have a market value on the spot of $\ell^{2} 75.8 d$. In addition to

1 Italics mine.

- High class Congo rubber, and the product from the Lopori (A.B.I.R.) district is excellent in quality, and fetches, not infrequently, over Io francs per kilo.-E. D. M. 
these formal payments, they were liable at times to be dealt with in another manner, for should their work, which might have been just as hard, have proved less profitable in its yield of rubber, the local prison would have seen them. The people everywhere assured me that they were not happy under this system, and it was apparent to a callous eye that in this they spoke the truth."

The above quotation is descriptive and explanatory of a scene in the Bongandanga district, part of the area allotted to the "A.B.I.R.," the objects of whose existence are, as we have spen, "Faire dans les limites les plus étendues toutes opérations commerciales. ..." and in which, as we have seen, the Congo Government is the largest shareholder.

My object in writing this article has been to place in the hands of the reader the key of the Congo question. I claim to have proved that throughout one million square miles of tropical African territory, "commercial" relationship between the European and the African has been eliminated as a factor in the political conception of its European rulers, and has been replaced by an entirely different conception. What is the nature of the new relationship? What are its effects to-day? What will be its effects to-morrow?

It is the greatest African question since the over-sea slavetrade set the intellectual world a-thinking, and, like the oversea slave-trade, its ramifications affect a far wider horizon than the psychology of the black races of mankind.

Is the honour of England, is the honour of France-between them the virtual over-lords of the Africa of the future--concerned in dealing with this question? Is it a question which the requirements of statesmanship alone, apart from all other considerations, demand should be dealt with? Or is it one which thoughtful men can consent, consistently with honour, with safety, with a remembrance of responsibility deliberately incurred and openly proclaimed, to see relegated to the next generation, by the indifferentism, the timidities, the vacillations of the hour?

E. D. MOREL. 